\title{
CLAUSAL SUBSTITUTION IN ENGLISH AND BULGARIAN
}

\author{
Snejana Obeyd ${ }^{1}$
}

\begin{abstract}
The article focuses on the ways and mechanisms clausal substitution in English works, thoroughly analysing said cohesive relation along with some of its most typical instances. As the three environments in which clausal substitution exists are report, condition and modality, these are also explicitly defined.
\end{abstract}

Bearing in mind that the English sentences containing clausal substitutes demonstrate the most typical instances of clausal substitution, the study is based on English literary texts which are translated into Bulgarian. Each sentence has several variants of translation: the original published version of the book in Bulgarian as well as the possible variants provided by the author, thus showing the various elements and devices corresponding to English clausal substitutes. The most representative ones are, in turn, analysed and categorized. As a result, the article also describes and discusses the different means through which cohesion is rendered in Bulgarian.

Key words: cohesion, substitution, clausal substitute, presupposition, relation

\section{Introduction}

A text is deemed cohesive when all the components within are interrelated so that it can be perceived as a unified entity, semantically and structurally (Halliday \& Hasan, 1976). As the meaning is delivered by forms, and the forms, in turn, by sounds and letters, cohesion integrates all text constructing mechanisms. For Halliday and Hasan (1976), cohesion is a semantic relation between an element in the text and some other one that is essential for its decoding. Cohesion expresses "the continuity that exists between part of the text and another" (ibid., p.288). Cohesive relations are realized through grammar as well as through vocabulary, i.e. through the establishment of semantic links between sentences on a surface level. There are three different kinds of relations in language that connect one party of a text with another: relatedness of form, relatedness of reference and semantic connection (ibid., p. 28)

In this article my focus is on the cohesive relation of substitution which is a formal relation between elements at the lexicogrammatical level. Substitution means the replacement of an item with another one, a filler word, retaining the grammatical function of the word for which it stands. Being a grammatical

1. Senior lecturer, Department of English Studies, Shumen University, Bulgaria, e-mail: s.obeyd@shu.bg, ORCID: 0000-0002-0676-5560 
relation, or as Halliday and Hasan (1976) put it: "a relation in the wording", the criterion for differentiating the types is the grammatical function of the substitute item. Structurally, substitution is operative at three levels:

Nominal: one/ ones, same

Verbal: $d o$

Clausal: so, not

My primary concern is to characterize clausal substitution as a text-forming agency in English and Bulgarian.

\section{Background studies}

A text is defined by Beaugrande and Dressler (1981) as "a communicative occurrence which meets seven standards of textuality." They make a distinction between cohesion and coherence. In their opinion, cohesion "concerns the ways in which the components of the surface text, i.e. the actual words we hear or see, are mutually connected within a sequence", while coherence refers to the meaningful relations in a text establishing "a continuity of senses" (ibid.). As surface components depend upon each other according to "grammatical forms and conventions", they view cohesion as a grammatical dependency.

A number of linguists (Beaugrande \& Dressler, 1981; Brown \& Yule, 1983; Dobreva \& Savova, 2000; Halliday \& Hasan, 1976; Harweg, 2001; Leech \& Quirk, 1985; Salkie, 1986; Todorova, 2015) have been concerned with the principles of connectivity, which bind a text together. Halliday and Hasan (1976) argue that the primary determinant of whether a set of sentences do or do not constitute a text depends on the cohesive relationships between the sentences, which create texture. Cohesive relationships within a text are set up "where the interpretation of some element in the discourse is dependent on that of another. The one presupposes the other in the sense that it cannot be effectively decoded except by recourse to it" (Halliday \& Hasan, 1976, p. 4). They consider cohesion a semantic relation which is realized through grammar as well as through vocabulary (ibid.). Altogether, they regard language as a "multiple coding system" with "three levels of coding: the semantic, the lexicogrammatical and the phonological and orthographic". (1976, p. 5)

Brown and Yule recognize Halliday and Hasan's view of the subject as being "the most comprehensive treatment" (1983). Although they provide an extended discussion of the relationships signaled by cohesive markers they agree that "it is the underlying semantic relation [...] that actually has the cohesive power" (Halliday \& Hasan, 1976, quoted in Brown \& Yule, 1983, p.195).

Cohesion is interpreted differently by different linguists. R. Todorova describes cohesion as "connectiveness between linguistic occurrences in text on surface 
level" (2015). She refers to substitute items as "pro-forms". In fact, the two terms appear to be interchangeable in most of the linguistic studies. The mechanism of work of "pro-forms" is presented as a replacement of "content-carrying elements with short place-holders of no independent content" (Beaugrande \& Dressler, 1981).

The first exploration of the unity of text has been proposed by Ronald Harweg, who stated that the mechanism of substitution is the major factor for texts to stick together. This is achieved by a sequence of expressions of the same sense or reference, which in turn realizes "a cohesive or coherent relationship" (Harweg, 1978, quoted in Brown \& Yule, 1985, p. 201). His notion of substitution turns out to be extremely complex, including "relationships such as recurrence, synonymy, class/instance, subclass/ superclass, cause/ effect, part/ whole, and much more" (Beaugrande \& Dressler, 1981).

For R. Quirk "substitution is a device for abbreviating and for avoiding repetition" (1973). The term "pro-form" in his analysis equals the term "substitute" and his classification distinguishes four types: pro-forms for noun phrases, adverbials, predicate and predication, and complex pro-forms.

In A Comprehensive Grammar of the English Language, Quirk et. al. define substitution as "a relation between pro-form and antecedent whereby the pro-form can be understood to have 'replaced' a repeated occurrence of the antecedent" $(1985$, p. 863). According to them there should be a grammatical and semantic equivalence between the "pro-form" and its "antecedent".

Dobreva and Savova (2000) present the most detailed account of the means and mechanisms in Bulgarian realizing the deep structure links on the surface level of text. For them, there are lexical means, such as pronouns, synonyms and repeated items that can function as replacements of an item(s), but the substitutive function of these lexical means is not their single one (ibid.).

Substitution, as Halliday and Hasan argue, is "a lexicogrammatical relation, in which a form (word or words) is specified through the use of a grammatical signal indicating that it is to be recovered from what has gone before" (1976, p. 308). They point out that the source of recovery is the text and the "grammatical signal" is, in fact, a substitute word, serving as a "sort of counter which is used in place of the repetition of a particular item" (ibid., p. 308).

\section{Analysis}

Clausal substitution may extend over more than the head of the substituted item, and it involves the presupposing of a whole clause. The substitutes so and not are used in clausal substitution (see Obeyd, 2013): 
[1] Are you coming to dinner? I think so.

[2] Did he leave on time? I think not.

In the example (1), so stands for I am coming to dinner; in (2) not substitutes for he didn't leave on time. Halliday and Hasan (1976: 131) describe three environments in which clausal substitution takes place. These are reported clauses (4), clauses of condition (5) and modality (6):

[4] Mary thinks that there is another planet beyond Pluto. But no one else thinks so.

(cited in Salkie, 1995, p.56)

[5] Would the girls miss the package she had put down? If so, would she remember that Erica had been close by?

(Hailey, 1971, p.120)

[6] "I dare say you never even spoke to Time!"

"Perhaps not."

(cited in Halliday, 1985, p.297)

All these three contexts that allow for clausal substitution to take place are semantically related. They provide an environment for the truth of the statement to be open to question. As Halliday and Hasan have put it: "all three types have the property of being one remove from (statements of) reality: they are hypothetical" (1976, p.136).

At first sight it would seem that clausal substitutes cannot be used to make a contrast, since they replace a whole clause. However, the clause is projected in a new contrastive context, which does not necessarily reject some other one, but there should always be "some redefinition of the environment of the presupposed clause" (Halliday \& Hasan, 1976, p.136). That is the main principle of clausal substitution, which also applies to substitution as a whole.

As I have already mentioned, clausal substitution operates within three environments. One of them is the conditional structure, as in [5]. The condition in this sample is expressed by if, which is outside the presupposition and provides the contrastive setting for the use of the substitute. Since it is a clausal substitute, so presupposes the whole of the previous clause the girl would miss the package she had put down.

The corresponding Bulgarian translations are as follows:

$\left[5_{1}^{2}\right]$ Дали момичето щеше да открие липсата на пакета? Ако това стане, дали щеше да си спомни....?

2. Subscript [1] marks the published Bulgarian translation of the example, while [2] and [3] provide the additional variants supplied by the author. 
$\left[5_{2}\right]$ Дали продавачката щеше да забележи липсата? И ако я забележи.......?

In [5] the impersonal verb ставам introduces the demonstrative това, which is in fact the semantic nucleus of the predication. Това refers to the whole of the preceding sentence, including it as fact. Hence, the mechanism by means of which a part of the English clausal substitute so is projected into Bulgarian is pronominalization. On the other hand, the expression това става stands for the previous sentence and since the verb ставам has an abstract lexical meaning the construction could be considered as substitutive for clauses denoting a particular state of affairs.

In $\left[5_{2}\right]$ the impersonal pronoun $я$ stands for the noun лuncama, which is an instance of pronominalization. There is an obvious structural gap with regard to the subject of the sentence продавачката and it proves that ellipsis is also in action. There is lexical repetition as well, realized by repeating the verb забелязвам.

Another environment suitable for the use of clausal substitutes is that of report. A typical reporting verb is say:

[7] Matt stopped, realizing that he had not really been talking to this brash kid DeLosanto - much as he disliked him - but that his own emotions, pent up inside, had suddenly burst through. He was about to say so, awkwardly, and add that he was sorry, when Barbara appeared...

$$
\text { (Hailey, 1971, p.187) }
$$

So substitutes the previous clause that his own emotions, pent up inside, had suddenly burst through. In this case, the form expressing the report coincides with that of the fact, but this does not mean that the relation is semantic. No matter whether there was a speech act or not, the report realizes relation in the wording.

The Bulgarian equivalents are as follows:

$\left[7_{1}\right]$...Без да иска беше дал израз на емоциите си, които дълго се бяха трупали в душата му. Понечи да каже всичко това на глас и да се извини, когато...

$\left[7_{2}\right]$...Тъкмо щеше да го каже и притеснено да добави, че съжалява...

$\left[7_{3}\right]$ Тъкмо щеше да изрече тези думи и неловко да се извини...

In [7, ] the pronominal expression всичко това stands in place of the substitute so. Semantically, всичко is quantifying summary pronoun, presenting its referent as a unity of elements. Since it is used attributively its referent is displayed by the demonstrative това, which in turn refers to the previous statement. Hence, the mechanism realizing the link is pronominalization. 
$\left[7_{2}\right]$ is also an instance of pronominalization. The difference is in the ThemeRheme organization of the text. While всичко това represent the culmination, the Rheme of the message, the short form of the pronoun 20 remains between the two poles, in the transitory part between the Theme and Rheme (see Nitsolova, 1986, p.53).

$\left[7_{3}\right]$ presents an instance of nominalization of a clause. As an anaphoric item the demonstrative тези has only identifying function, that is, it identifies that it

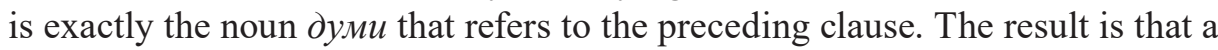
stretch of text is transformed into a nominal phrase.

Some reporting verbs require the negation to be transferred into the reporting clause, so that we cannot normally use the negative clausal substitute, but the positive so. The most frequently used verb in such cases is think:

[8] "Surely being a newspaper writer is doing something useful." ... "If you saw as much of press people as I do, you might not think so."

(Hailey, 1971, p.127)

As we see, reporting is associated with thinking, since there is a correspondent act of verbalizing the thought. In this example so replaces the clause being $a$ newspaper writer is doing something useful.

The alternative translations to this sample are the following:

$\left[8_{1}\right]$ - Писането на статии в печата сьщо е полезна работа.

- Ако познаваше толкова журналисти, колкото (познавам) аз/ мен, сега щеше да си на друго мнение.

$\left[8_{2}\right]$ - .....нямаше да мислиш така.

$\left[8_{3}\right]$ - ....нямаше да си на това мнение.

[8] is organized by means of nominalization, expressed by друго мнение. The lexical item друг is considered opposite to the demonstrative такъв with regard to the characteristic "identity of referents". Hence, it also functions as pronominal item designating non-identity of referents as a result of their comparison as well as non-identity of their properties. On account of its attributive and pronominal nature it realizes the anaphoric link between the noun мнение and the previous clause.

In $\left[8_{2}\right]$ the anaphoric item is the pronominal adverb така, presupposing the previous statement.

In $\left[8_{3}\right]$, the whole of the preceding clause is presented in a synthesized way by means of the demonstrative това identifying the nоun мнение as coreferent with the preceding statement. 
Usually, a question-answer sequence in a dialogue provides the most suitable environment for the use of clausal substitutes. This is a result of the hypothetical nature of some of the answers. They can express agreement or disagreement with the truth of the proposition as well as leaving it to be open to question. The following is an example of such a sequence of question-answer:

[9] "I know how you do everything - always the same way, thoroughly. So it will involve a lot of time. Well, won't it?'

He conceded, "I suppose so."

"Will it be in office time? In the daytime, during the week?"

"Probably not."

(Hailey, 1971, p.134)

In its first occurrence, so is the additive conjunction, meaning "accordingly". In the next, it is the clausal substitute so used within the context of report. The reported clause for which so stands is it will involve a lot of time. The reported clause is dependent on the reporting one, thus so presupposes a clause that is hypotactically related to that containing the verb suppose. No matter whether the presupposed clause is interrogative, the reported clause for which so stands is always declarative.

Another possible context for the use of so and not is that of modality. Most often modality is expressed within the clause by a modal adverb, in this case probably and there is no dependency involved. However, the perimeter of clausal substitution spreads to this realization. Not replaces it won't be in office time, in the daytime, during the week, and the contrast is expressed by probably, which is beyond the range of the presupposition.

Here are the translated versions of this sample:

$\left[9_{1}\right]$ - Аз зная как ще го направиш - задълбочено и подробно като всичко, за което се залавяш. А това изисква много време, нали?

- Предполагам - съгласи се той.

- Но няма да използваш работното си време, през деня, през седмицата...

- Вероятно не.

$\left[9{ }_{2}\right]-$ За това ще ти трябва оста време, нали? - Предполагам, че да.

- В работното ти време ли ще е, през деня, в делничните дни?

- Вероятно не.

In [9] , in the place of $s o$, there is ellipsis of the dependent ye-clause, which is to be supplied from the preceding sentence. The modal verb предполагам арреars to be the presupposing item. By virtue of its transitive nature it functions as an 
elliptical clause in which everything except the predicate is presupposed. In $\left[9{ }_{2}\right]$, the same case is rendered by means of the elliptical ue- clause, consisting only of the affirmative particle $\partial a$. Semantically, $\partial a$ blocks the uncertainty implied by the verb and confirms the presupposition as positive. Both the negative не and the positive $\partial a$ particles are text-dependent, so in case they are used as the only element of a clause, this clause is considered elliptical.

In the two versions, the negative substitute not is translated by means of the negative particle $н е$. The construction is elliptical. The semantic function of $н$ in this example is almost the same as of $\partial a$ : it blocks the uncertainty of the modal adverb вероятно by transforming the presupposition into a negative one.

The following example illustrates the use of the negative substitute in the context of report:

[10] "Ever hear of a well-paid spy?" "I suppose not."

$$
\text { (Hailey, 1971, p. 468) }
$$

The substitute presupposes the clause I have never heard of a well-paid spy. There is a great extent of similarity in meaning between a reported clause dependent on a first person singular "cognizing" verb and a modalized clause, for example I suppose not could be interpreted as probably not. This results from their nature of hypothesis.

That example could be translated as follows:

$\left[10_{1}\right]$ - Чувал ли си някога за съществуването на наистина добре платени шпиони?

- Май не съм.

$\left[10_{2}\right] \ldots$ - Мисля, че не.

In both translated versions the case is rendered by means of ellipsis. In [10 ], the auxiliary verb $c b \cdot M$ functions as presupposing the rest of the predication. In $\left[10_{2}\right]$, it is the dependent ye-clause that is elliptical, consisting only of the negative particle marking only the polarity of the presupposition.

\section{Conclusion}

Condition, modality and report are the basic settings in which clausal substitution takes place in the analyzed text, and the contrastive element is outside the clause. The substitute items appear to be a manifestation of givenness, contributing to the semantic structure of a text without disturbing its informational organization.

The leading position among the means by which clausal substitutes are projected into Bulgarian is occupied by pronominalization. Demonstrative pronouns and 
adverbs are used on their own as substantivized items (nominators) carrying the information load presenting it as fact. Anaphoric expressions, realized by a demonstrative and a generalizing word frequently appear as projections of the substitute so when standing for a reported clause.

When a clause, sentence or a segment of text is taken up by a following item, transforming it into a noun nominal group, the mechanism of nominalization is realized. It comes into being by means of generalizing nouns, which either have an abstract meaning, thus expressing the neutral position of the author towards the referred part of the text, or have some interpersonal element in the meaning allowing the subjective views, characteristics and judgements to be expressed in an abbreviated way.

Ellipsis is activated in some cases of clausal substitution in Bulgarian, especially in question-answer sequences which provide a suitable setting for the realization of this mechanism. Both are grammatical devices that enable us to identify information which is given and in this way concentrate on new information.

The analysis shows that substitution as well as its corresponding equivalents in the Bulgarian versions of the material are resources that give "texture" to a piece of text. They make it possible to link items of any size and distance, whether structurally or not. They provide unity to the building of text so that it can function as a complete communicative entity.

\section{References:}

Brown, G., \& Yule, G. (1983). Discourse analysis. Cambridge: Cambridge University Press.

Collins Cobuild English Grammar (1990). London \& Glasgow: Collins.

De Beaugrande, R., \& Dressler, W. (1981). Introduction to text linguistics. London \& New York: Longman.

Dobreva, E., \& Savova, I. (2000). Tekstolingvistika. Shumen: Konstantin Preslavsky University Press.

Halliday, M.A.K (1985). An introduction to functional grammar. London: Edward Arnold.

Halliday, M.A.K., \& Hasan, R. (1976). Cohesion in English. London: Longman Group Ltd.

Harweg, R. (2001). Studien zur Textlinguistik. Shaker Verlag

Nitsolova, R. (1986). Bulgarskite mestoimeniya. Sofia: Nauka i Izkustvo

Obeyd, S. (2013) Clausal substitution. Dynamics, interdisciplinarity, diversity. Shumen: Konstantin Preslavsky University Press. 93-97.

Quirk, R., \& Greenbaum, S. (1973). A university grammar of English. Harlow: Longman 
Quirk, R., Greenbaum, S., Leech, G., \& Svartvik, J. (1985). A comprehensive grammar of the English language. London: Longman.

Salkie, R. (1995). Text and discourse analysis. London \& NewYork: Routlege.

Todorova, R. (2015). Insights in text linguistics. From theory to practice. Shumen: Konstantin Preslavsky University Press. ( $2^{\text {nd }}$ ed.).

\section{Sample text sources:}

Hailey, A. (1971). Wheels. New York: Doubleday \& Company, Ltd

Hailey, A. (1988). Kolela. (translated by Veselin Laptev). Sofia: Narodna kultura. 